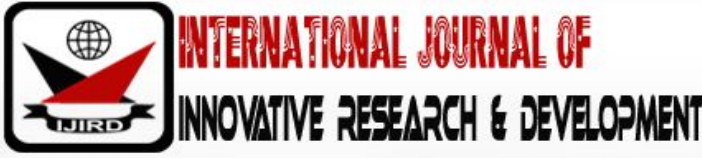

ISSN 2278 - 0211 (Online)

\section{Attitude of Teachers towards Students' Self-Assessment in Secondary Schools in Rivers State, Nigeria}

\author{
Dr. Chikwe, Christian K. \\ Senior Lecturer, Department of Educational Psychology, Guidance \& Counselling, \\ Ignatius Ajuru University of Education, Rumuolumeni, Port Harcourt, Nigeria
}

\begin{abstract}
:
The study investigated attitude of teachers towards students' self-assessment in secondary schools in Rivers State. The study adopted the descriptive survey design. Two research questions and two hypotheses guided the study. Population of the study comprised all secondary school teachers in Rivers State. The stratified random sampling technique was used to draw the sample of 800 teachers. The instrument for data collection was a questionnaire titled: "Attitude of Teachers toward SelfAssessment Questionnaire (ATTSAQ)". The research questions were answered with simple percentage, while the hypotheses were tested with chi-square. The result of the study showed that attitude of teachers towards students' self-assessment was positive. There was no significant difference between the attitude of male and female teachers towards students' selfassessment. Also, the attitude of urban and rural teachers towards students' self-assessment was not statistically significant. The study recommended that the use of self-assessment method as an alternative assessment technique should be encouraged in secondary schools.
\end{abstract}

Keywords: Self-assessment, teachers, attitude

\section{Introduction}

Learning is not complete without assessment. To determine whether learning has taken place is achieved by means of assessment. Assessment is the process of collecting data and organizing the data collected into an interpretable form on the basis of which judgement or evaluation could be made (Obimba, Asuru as cited in Chikwe, 2017). There are different forms of assessment such as continuous assessment, school-based assessment, computer-based assessment, peer-assessment, and selfassessment. Continuous assessment according to Agbaegbu (1997) is a systematic and objective process of determining the extent of student's performance in all expected changes in behaviour of all information derived with a view to using them help the student. Continuous assessment is also the type of assessment whereby the final grade or performance of a student takes into account his previous performances in all areas of domain (cognitive, affective and psychomotor) from the time of entry into school to the time of exit. School-based assessment is the use of valid and reliable tests, observations, questionnaire, interviews and other instruments in obtaining information about students' behaviour upon which judgment is made. It is also the process and tools teachers use to make decisions about their students' progress (Osadebe, Ndege in Chikwe, 2017). Computer-based assessment makes use of computer in the assessment of students. Peer assessment is the use of students in the evaluation/ assessment of the extent to which they have performed or learned what they were taught in the teachinglearning process.

On the other hand, self-assessment according to Boud (1995, p. 12) is the involvement of students in identifying standards and/ or criteria to apply to their work and working judgements about the extent to which they have met these criteria and standards. Andrade and Du in Spiller (2012, p. 3) defined self-assessment as "a process of formative assessment during which students reflect on and evaluate the quality of their work and their learning, judge the degree to which they reflect explicitly stated goals or criteria, identify strengths and weaknesses in their work and revise accordingly. Selfassessment from the definitions above is the method whereby students undertake the assessment of their learning or performance after the teaching-learning process. The students are given the opportunity to make input in their assessment and evaluation of their work. This method has shown that students are more actively engaged when allowed to participate in the assessment process.

The importance and benefits of self-assessment cannot be overemphasized. The various reasons for self-assessment have been identified by Spiller (2012) as follows:

- It builds on a natural tendency to check out the progress of one's own learning;

- It motivates students for further learning; 
- It encourages reflection on one's own learning;

- It can promote learner responsibility and independence; and

- Encourages student ownership of the learning, etc.

Self-assessment helps prepare students not just to solve the problem we already know the answer to, but to solve problems we cannot at the moment conceive (Brew, 1995 in Spiller, 2012). Self-assessment deepens learners understanding of what constitute quality outcomes in a specified area.

Self-assessment therefore as an innovation in assessment can enhance students' learning by stimulating their interest in learning and elicit more attention and focus during classroom activities. Self-assessment uses students in the evaluation of their progress, developing their communication skills, and increases their mathematical vocabulary (Stallings \& Tascione cited in Gunawardena, 2010).

Self-assessment can be used for various purposes. Boud as cited in Gunawardena (2010) explained uses of selfassessment in eight major categories such as, for individual self-monitoring and checking progress for promoting how-to-learn skills, for diagnosing and remediation, as a substitute for other forms of assessment, to improve professional or academic practice, to consolidate learning over a wide range of contexts, to review achievement as a prelude to recognize prior learning, and for self-knowledge and self-understanding.

Some studies have been carried out on students' self-assessment. Zachary, Fein and Heidi (2012) in a pilot study carried out a study on Student Self-Assessment in middle school mathematics. The purpose of their study was to design a process of self-assessment for seventh grade mathematics students and test its effectiveness in improving performance. The result of the study revealed a statistically significant association between self-assessment and performance. Brookhart, Andolina, Zuza and Furman as cited in Warner, Chen and Andrade (2012) established that the involvement of third grade students in their own assessment improved not only their mathematics but narrowed the gap between their predicted and actual performance. Stallings and Tascione (1996) observed that the process of self-assessment can "engage students in evaluating their progress, aid in developing their communication skills, and increase their mathematics vocabulary" (p. 548). Abdallah (2010) found that students self-assessment had positive effect on their performance in reading in English. The study recommended that students be trained on how to use self-assessment, and that instructors (teachers) should be aware of the positive effect of student self-assessment on their performance in reading. Also, Heidarian (2016) found that there is statistically significant increase in the learner's use of writing as a result of using self-assessment method and their writing has developed. The study concluded that using self-assessment as an assessment method is an effective instructional technique and a useful evaluation instrument. Literature reviewed so far on the students' self-assessment has shown a positive relationship between students' self-assessment and performance in English, Mathematics.

Bramwell-Labor and Rainford (2016) investigated advanced level biology teachers' attitudes towards assessment and their engagement in assessment for learning. They described the teachers' experiences while being engaged in assessment for learning practices such as sharing of learning objectives and peer-and self-assessment. Quantitative data were collected from 40 teachers using the researcher-constructed Teachers' Attitude towards Assessment Questionnaire. The findings revealed that advanced level biology teachers displayed highly favourable attitude towards assessment. The teachers highlighted the usefulness of practices such as the learning objectives and students' engagement in self-assessment.

Khoshsima, Mohammadi and Mustafa Pour (2016) carried out a study on a comparative study of students and teachers' attitude toward self-assessment: A case of trainman context. They used 120 teachers and 120 students for the study. Data was analyzed using descriptive statistics, frequency counts, and percentages. The results showed that there was a significant effect of self-assessment initiatives in enhancing the students' willingness and ability to engage in self-assessment and in creating positive outlooks toward English Language learning.

In a study by Lin and Gan (2014) on Taiwanese students' use of English listening strategies and self-regulated learning and self-assessment, the study concluded that self-regulated learning made students plan and evaluate their own education, gave them a desire to acquire the knowledge, motivated them to succeed, and take action to become proficient. Hence, selfregulated learning involving self-assessment helped learners to be more active in their learning, etc.

Ibberson (2012) investigated into learners' and teachers' attitudes towards learners' self-assessment according to CEFR scale. The study was carried out to compare the learners' attitude towards self-assessment based on the CEFR's rating scales and also to compare with teachers' attitude. Data was collected through a structured questionnaire and a follow-up interview of 20 English learner and 2 teachers in the United Kingdom (UK). The results revealed that both learners and the teachers had positive attitudes towards self-assessment.

\subsection{Statement of the Problem}

Self-assessment has been an area of interest to educationists, evaluation experts and stakeholders in education in recent times. The dwindling performance of students could it be attributed to the attitude of teachers towards the assessment method used in evaluating students during and after the teaching-process. The paper therefore is undertaken to determine attitude of teachers towards students' self-assessment method of evaluating students learning in secondary schools in Rivers State.

\subsection{Research Questions}

The following research questions guided the study: 
- What is the attitude of male and female teachers towards students' self-assessment method in secondary schools in Rivers State?

- What is the attitude of teachers in urban and rural schools towards students' self-assessment method?

\subsection{Hypotheses}

The following hypotheses were formulated to guide the study:

- There is no significant difference between the attitude of male and female teachers towards the self-assessment method in secondary schools in Rivers State.

- There is no significant difference between the attitude of teachers in urban and rural schools towards students' selfassessment method in secondary schools in Rivers State.

\section{Methodology}

The study adopted the descriptive research design method. The study comprised teachers in public secondary schools in Rivers state. A sample of 800 teachers was selected using the stratified random sampling technique. The instrument for data collection was a self-designed questionnaire titled, "Attitude of Teachers towards Self-Assessment Questionnaire (ATTSAQ)". The ATTSAQ was a 2-point scale of Yes/ No. the reliability coefficient of 0.78 was obtained which was considered acceptable. The research questions were answered with percentage, while the hypotheses were tested with the Chi-square statistics.

\section{Results}

\subsection{Research Question One}

What is the attitude of male and female teachers towards students' self-assessment in secondary schools in Rivers State?

\begin{tabular}{|c|c|c|c|}
\hline \multicolumn{4}{|c|}{ Attitude } \\
\hline Gender & Positive (\%) & Negative (\%) & Total (\%) \\
\hline Male & $46(368)$ & $24(192)$ & $560(70)$ \\
\hline Female & $19(152)$ & $11(88)$ & $240(30)$ \\
\hline Total & $65(520)$ & $35(280)$ & $800(100)$ \\
\hline
\end{tabular}

Table 1: Percentage Analysis of Attitude of Male and

Female Teachers towards Self-Assessment

Table 1 shows that $65 \%$ of the teachers have positive attitude while $35 \%$ have negative attitude, all towards students' self-assessment. Among the male teachers, $46 \%$ have positive while $24 \%$ have negative attitude. Among the female $19 \%$ have positive attitude while $11 \%$ have negative attitude, all towards students' self-assessment.

\subsection{Research Question Two}

What is the attitude of teachers in urban and rural schools towards students' self-assessment method?

\begin{tabular}{|c|c|c|c|}
\hline \multicolumn{4}{|c|}{ Attitude } \\
\hline School Location & Positive (\%) & Negative (\%) & Total (\%) \\
\hline Urban & $63(504)$ & $17(136)$ & $80(640)$ \\
\hline Rural & $15(120)$ & $5(40)$ & $20(160)$ \\
\hline Total & $78(624)$ & $22(176)$ & $100(800)$ \\
\hline
\end{tabular}

Table 2: Percentage Analysis of Attitude of Male and

Female Teachers towards Self-Assessment

Table 2 shows that $78 \%$ of the teachers in urban and rural schools have positive attitude while $22 \%$ have negative attitude, all towards students' self-assessment. Among the teachers in urban schools $63 \%$ have positive attitude while $17 \%$ have negative attitude. Among teachers in rural schools 15\% have positive attitude while $5 \%$ have negative, all towards students' self-assessment method in secondary schools in Rivers State.

\subsection{Hypothesis One}

There is no significant difference between the attitude of male and female teachers towards students' self-assessment method in secondary schools in Rivers State. 


\begin{tabular}{|c|c|c|c|}
\hline \multicolumn{4}{|c|}{ Attitude } \\
\hline Gender & Positive (\%) & Negative (\%) & Total (\%) \\
\hline Male & $46(45.5)$ & $24(24.5)$ & 70 \\
\hline Female & $19(19.5)$ & $11(10.5)$ & 20 \\
\hline Total & 65 & 35 & 100 \\
\hline
\end{tabular}

Table 3: Chi-Square $\left(\mathrm{X}^{2}\right)$ Analysis of Significant Difference between Attitude of Male and Female Teachers towards Students' Self-Assessment

Chi-square $\left(\mathrm{x}^{2}\right)$ calculated value $=0.0523$

Chi-square $\left(\mathrm{x}^{2}\right)$ critical value $=3.84$

Degree of freedom $=1$

Significant level $=0.05$

Since the calculated $\mathrm{x}^{2}$ - value (0.0523) is less than the critical or table $\mathrm{x}^{2}$ - value (3.84) the null hypothesis of no significant difference is accepted. Therefore, there is no significant difference between male and female teachers towards students' self-assessment method.

\subsection{Hypothesis Two}

There is no significant difference between the attitude of teachers in urban and rural schools towards students' selfassessment method in secondary schools in Rivers State.

\begin{tabular}{|c|c|c|c|}
\hline \multicolumn{4}{|c|}{ Attitude } \\
\hline School location & Positive (\%) & Negative (\%) & Total (\%) \\
\hline Urban & $63(62.4)$ & $17(17.6)$ & 80 \\
\hline Rural & $15(23.4)$ & $5(4.4)$ & 20 \\
\hline Total & 78 & 22 & 100 \\
\hline
\end{tabular}

Table 4:Chi-Square (X2) Analysis of Significant Difference between Attitude of Teachers in Urban and Rural School towards Students' Self-Assessment

Chi-square $\left(\mathrm{x}^{2}\right)$ calculated value $=0.471$

Chi-square $\left(\mathrm{x}^{2}\right)$ critical value $=3.84$

Degree of freedom $=1$

Significant level $=0.05$

Since the calculated $\mathrm{x}^{2}$-value $(0.471)$ is less than the critical or table $\mathrm{x}^{2}$-value (3.84), the null hypothesis of no significant difference is accepted. The result is that there is no significance difference between teachers in urban and rural schools towards students' self-assessment method in secondary schools in Rivers State.

\section{Discussion}

The result of research question one showed that the attitude of male and female teachers towards students' selfassessment method was positive. In other words, majority of the teachers were favourably disposed to self-assessment as alternative method of assessment. The result of the null hypothesis revealed that there was no significant difference between the attitude of male and female teachers towards the students' self-assessment method in secondary schools in Rivers State. This implied that the observed difference in the attitude of male and female teachers towards self-assessment was not statistically significant.

This result is in agreement with Brammellhalor and Rainford (2016) who reported that advanced level Biology teachers displayed highly favourable attitudes towards assessment, and the teachers highlighted the usefulness of practices such as the learning objectives and student's engagement in self-assessment. Also, Khoshsima, Mohammdi and Mustafapour (2016) reported a significant effect of self-assessment initiatives in enhancing students' and ability to engaging selfassessment.

The result of research question two showed that these teachers in urban and rural have positive attitude towards selfassessment in secondary schools in Rivers State. Also, there was no significant difference between teachers in urban and rural schools in their attitude towards self-assessment. This finding is in line with Ibberson (2012) who reported teachers' positive attitudes towards self-assessment.

\section{Conclusion}

The teachers in this study had positive attitudes towards students' self-assessment. This was irrespective of the teachers' gender (male and female) and their school location (urban and rural). The teachers were favourably disposed to students' self-assessment method as an alternative method of assessment and can be used in enhancing students' learning and performance. There is therefore need to encourage teachers in secondary school to adopt self-assessment as a method of enhancing students' learning. 


\section{Recommendation}

Based on the findings of the study, the following recommendations are made:

1. The use of self-assessment method as an alternative assessment technique should be encouraged in secondary schools. This will give students opportunity to make input into their own assessment.

2. Awareness on the use of self-assessment should be created among teachers in secondary schools.

3. Short-term course, workshops and seminars should be organized to increase the knowledge of teachers on selfassessment.

\section{References}

i. Abdallah, A.B. (2010). The effect of the use of self-assessment on EFL students' performance in reading comprehension in English. The Electronic Journal for English as a Second Language, 14(2).

ii. Bramwell-Lalor, S. \& Rainford, M. (2016). Advanced level biology teachers' attitudes towards assessment and their engagement in assessment for learning. European Journal of Science and Mathematics Education, 4(3), 380-396.

iii. Chikwe, C.K. (2017). Test and measurement in education. Port Harcourt: Emmanest Ventures.

iv. Heidarian, N. (2016). Investigating the effect of using self-assessment on Iranian EFL learners' writing. Journal of Education and Practice, 7(28), 80-89.

v. Ibberson, H. (2012). An investigation into learners' and teachers' attitudes towards self-assessment according to CEFR' scales. Language at the University of Essex 2011 Proceedings (2012), 13-24.

vi. Khoshsima, H., Mohammadi, J. \& Mustafapour (2016). International Journal of Human and Cultural Studies, 3(1), 657674.

vii. Lin, C.Y, Gan, X.N (2014). Taiwanese college students' use of English listening strategies and self-regulated learning. International Journal of Stud ies in English Language and Literature, 2(5), 57-65.

viii. Warner, Z.B.; Chen, F. \& Andrade (2012). Student self-assessment in middle school mathematics: A pilot study. Northeastern Educational Research Association(NERA) annual conference proceedings 2012.5 http:/ / digitalcommons.uconn.edu/ nera-2012/ 5 